\title{
Radical Republicanism and the Future of Work
}

\begin{abstract}
I develop a socialist republican conception of economic liberty and show how it can be used to understand the domination of workers. It holds that both paid and unpaid workers can be deprived of economic freedom when they are exposed to an arbitrary power to undermine their access to the economic capabilities needed for civic equality. On the basis of this analysis, measures intended to reduce domination are recommended, including public ownership of productive property, workplace democracy, and robust unconditional basic income and services. Finally, I discuss the implications of this approach for platform capitalism, digital surveillance, the rise of automation, and post-work politics.
\end{abstract}

\section{Introduction}

The civic republican tradition might seem like a strange place to look for resources to think through the future of work. This is because its roots are found in ancient political practice, and its high-water mark in political thought arguably occurs in the early modern period, before the formation of industrial capitalism. ${ }^{1}$ Furthermore, the attempt to repurpose civic republicanism for emancipatory purposes can appear even more misguided, with sceptical commentators emphasising its debts to the "deeply hierarchical, sexist, imperialist and slave-owning society" of the Roman Republic, and posing the question, "Why should we think their formulations disarticulable in some unproblematic way from the discourses and practices of domination that suppressed and oppressed the very great majority of human beings in their world?"2

What such hostile verdicts often overlook is the way in which civic republican ideas were transformed later in their history by being taken up by working class labour movements in the 
nineteenth- and early twentieth-century. These encounters pushed republican thought in a radically egalitarian direction, while reshaping republican concepts in an attempt to get to grips with the nature of the dominating power held over workers by the capitalist class. My contention is that the radical republican conceptual framework which emerges from this encounter should inform our thinking about the future of work. I shall argue that a republican account of economic freedom can underpin both analytical and normative reflection about the changing nature and potential decline of work in the years to come. This republican approach rests on a conception of economic domination: people lack economic freedom to the extent that their access to the economic capabilities necessary to stand in relationships of civic equality is dependent on the arbitrary will of others. We can begin, however, by considering the rival market-driven understanding of economic freedom which shapes many contemporary approaches to the workplace and labour market.

\section{Market Freedom and Work}

The radical republican conception of economic freedom which I shall develop is an alternative to what is now the dominant approach of aligning economic freedom with free markets. For instance, an influential article by Niclas Berggren tells us:

"Economic freedom" means the degree to which a market economy is in place, where the central components are voluntary exchange, free competition, and protection of persons and property. ${ }^{3}$

Likewise, the Fraser Institute say,

Individuals are economically free when they are permitted to choose for themselves and engage in voluntary transactions as long as they do not harm the person or property of others. [...] Economic freedom is reduced when taxes, government expenditures, 
and regulations are substituted for personal choice, voluntary exchange, and market coordination. ${ }^{4}$

What are the implications of this market conception of economic freedom for workers? Minimum wage legislation, limits on working hours, and the banning of zero-hours contracts and fire-at-will clauses would all make workers less free by limiting what kind of contracts they can enter with employers. Furthermore, income taxes will also deprive people of economic freedom - at least, when they exceed the minimum necessary to secure the conditions for voluntary exchange, such as basic security and civil order. While supporters of progressive policies might accept that they reduce economic freedom yet find other grounds for advancing them, the more effective response is to challenge the market conception of freedom driving this analysis.

There is nothing natural and inevitable about market conceptions of economic liberty. They arose in response to particular political, social, and economic developments in modernity, and were entrenched through a concerted ideological effort. Nowhere is this more visible than the postbellum United States, where the ideal of liberty of contract founded on self-ownership, consent, and exchange was championed most explicitly. ${ }^{5}$ William Graham Sumner, the liberal sociologist, articulated this ideal in general terms when he asserted that a "society based on contract is a society of free and independent men, who form ties without favor or obligation, and cooperate without cringing or intrigue". ${ }^{6}$ More specifically, abolitionists such as William Lloyd Garrison could celebrate former slaves as "Freedmen at work as independent laborers by voluntary contract!" ${ }^{7}$ While some charged that little had changed for freedmen, with a mere shift from chattel slavery to wage-slavery, Garrison retorts, "May he not contract for his wages? [...] Does he not own himself?"8 The liberal journalist E.L. Godkin arrived at similar conclusions about workers more widely, remarking that we "submit our social relations more and more to the dominion of contract simply. The laborer passed out of the domain of status 
long ago." This belief in the movement from hierarchical status to contract informs his conception of liberty for workers, which he takes to amount to the "liberty to buy and sell, mend and make, where, when, and how we please". ${ }^{10}$

When this understanding of freedom was incorporated into legal practice, it spelled disaster for the conditions of many workers. For instance, legislation against sweatshops and the establishment of maximum hours of work which feminists had pushed for was struck down for violating a woman's equal contractual freedom to labour as she wished. ${ }^{11}$ The famous Lochner decision of the Supreme Court in 1905 similarly held that a New York law that required bakers not to work more than 10 hours a day or 60 hours a week was an "unreasonable, unnecessary and arbitrary interference with the right and liberty of the individual to contract". ${ }^{12}$ On similar grounds, the courts invalidated laws which prevented employers paying miners in 'scrip' - coupons that could only be used in company stores. If workers entered voluntary contracts to be paid in such a way, who was the state to stop them? Likewise, the prohibition of 'yellow dog' or 'iron-clad' contracts - forbidding workers to "enter into or in any way aid or sanction any strike or combination" - was found to be a violation of the right of personal liberty. ${ }^{13}$ Again, it was supposed by the courts that workers' decisions to be bound by such agreements had to be respected out of deference to their liberty of contract. Thus, the union leader John Mitchell could astutely say that workers were "being guaranteed the liberties they do not want and denied the liberty that is of real value to them". ${ }^{14}$

\section{Radical Republicanism}

If we want a progressive or radical alternative to this market conception of economic liberty, with its insidious implications for workers, then we might be doubtful that republican political thought can offer us it. Consider the first of two dimensions of economic liberty that John 
Tomasi distinguishes: the liberty of owning. ${ }^{15}$ The ancient republican Cicero says, "it is the proper function of a citizenship and a city to ensure for everyone a free and unworried guardianship of his possessions". ${ }^{16}$ This leads him to oppose property taxes, redistributive agrarian reform, and debt forgiveness. Likewise, the later republican Algernon Sidney claims that so long as no harm is done to the public, "I am protected in the peaceable enjoyment and innocent use of what I possess". ${ }^{17}$ We find here a defence of individual property which does not appear fundamentally opposed to later market-centric protections for private property.

The same could be said of what Tomasi calls liberties of working. Sidney notes that "society leaves me a liberty to take servants, and put them away at my pleasure." Furthermore, he says, "if there be a contest between me and my servant concerning my service, I only am to decide it: He must serve me in my own way, or be gone if I think fit, tho he serve me never so well". ${ }^{18}$ This foreshadows the defence of fire-at-will employment found in contemporary commercial republicans like Robert Taylor. ${ }^{19}$ So, the prospects for a progressive republican account of economic freedom that can inform thinking about the future of work might not seem very strong. But this prognosis begins to change if we look to the way workers in the nineteenth-century took up republican language and ideas, such as the labour republicans most closely associated with the nationwide American labour federation, the Knights of Labor.

The Knights drew upon republican ideas - even quoting Sidney's account of freedom and slavery, which tells us,

The weight of chains, number of stripes, hardness of labour, and other effects of a master's cruelty, may make one servitude more miserable than another: but he is a slave who serves the best and gentlest man in the world, as well as he who serves the worst; and he does serve him if he must obey his commands, and depends upon his will. ${ }^{20}$ 
Sidney is here restating the republican thesis that liberty is opposed to slavery, and that the mark of the slave is subjection to the arbitrary power of another. Those in a state of unfreedom are vulnerable to a master's arbitrium or judgement. For instance, even the skilled Roman slave with a cushy administrative job and without much interference with their actions still cannot claim to be free. Why is that? It is because their position is enjoyed entirely at the indulgence of their master - who could have them beaten bloody and sent down the mines whenever he fancies. Slaves always have to walk on eggshells for risk of upsetting their masters. The lesson here is that freedom is undermined by relationships of domination: those in which someone is vulnerable to another person's arbitrary power, even when that power is not presently being used. Historically, republicans have drawn on this kind of analysis to attack the arbitrary power of princes and magistrates, with Sidney turning republican ideas about liberty against the king: even if you have the gentlest ruler in the world, you are unfree if you are simply subject to their will. But we have seen that Sidney does not draw the conclusion that we should oppose employment relationships where analogous power dynamics obtain.

When the Knights asked themselves, "What is it to be a SLAVE?" then they answered, "It is to be a person consciously capable of self-government, and to be, at the same time, subject to the will of another person."21 Unlike Sidney, the Knights sought to extend this idea to the economic realm and the status of working people, with George McNeill complaining about a failure to "engraft republican principles into our industrial system". ${ }^{22}$ Their Journal of United Labor asks rhetorically, "Is there a workshop where obedience is not demanded - not to the difficulties or qualities of the labor to be performed - but to the caprice of he who pays the wages of his servants?" ${ }^{23}$ Here we find a republican conception of freedom as security against arbitrary power being put to use to criticise waged labour. Hostility to waged labour is by no means unprecedented among earlier republicans and their forebears, such that we can find Aristotle condemning such work as servile, and concluding that "it is the mark of a free man 
not to live at another's beck and call." ${ }^{24}$ But the egalitarian commitments of the labour republicans entailed that this was not a condition that was merely to be avoided for oneself whilst foisted onto others. Instead, economic systems which presupposed such dominating power had to be dismantled.

The radical republican opposition to arbitrary power vested in the hands of employers is taken forward by later socialists in their analysis of the workplace. For instance, the great socialist organiser and orator Eugene Debs strikes a radical republican note when he says "the great mass struggle in economic servitude. [...] No man is free in any just sense who has to rely upon the arbitrary will of another for the opportunity to work." 25 The familiar republican contrast between freedom and dependence upon another's arbitrary will should be unmistakable in this passage. Debs also adopts a republican contrast between mastery and servitude rather than understanding freedom in the workplace as something secured by voluntary agreement guaranteed by a labour contract.

Both tropes are combined in Debs' attempts to show that political equality was impossible while workers lacked economic freedom:

The wage-worker whose employment is controlled by his industrial master, and who in that relation is at the mercy of his master since he depends upon his arbitrary will for the opportunity to labor and support his family, is not on terms of political equality with his master. ${ }^{26}$

Thus, Debs concludes, “[p]olitical equality is rooted in economic freedom”, and such freedom will not be achieved until "the means of production shall have become the common property of all”. What Debs shows us is that a republican account of liberty - one which takes subjection to a master's will to be the mark of unfreedom - can justify a radical transformation of economic relationships. We here find a labour republican analysis of arbitrary economic power 
issuing not simply in a recommendation for large-scale cooperative production but a socialist programme of public ownership.

Debs was a committed socialist but nevertheless makes clear that what is sought is "absolute economic freedom for the individual". ${ }^{27}$ The conditions for securing this freedom, however, are thoroughly social. They begin with the socialisation of productive property, underpinning a democratisation of economic power, and encompass relationships of solidaristic cooperation which will ultimately abolish the servitude brought about by waged labour. Socialist republicans need not be embarrassed that they are seeking freedom for the individual, since this freedom is premised on collective democratic control of the economy, with the project of achieving the freedom of each being bound up with seeking the freedom of all. $^{28}$

\section{Republican Economic Liberty}

What lessons about economic freedom can we draw from such a radical republican approach? I want to propose that we take economic freedom to consist in relational economic independence. Someone is economically free when they are not economically dependent in ways that subject them to the arbitrary will of another. We can spell this out more fully negatively: you lack economic freedom when your access to the economic capabilities necessary to stand in relationships of civic equality is dependent on the arbitrary will of

others. ${ }^{29}$ If we return to Tomasi's distinction, we can say that economic liberty of ownership requires that each citizen can use and control the economic goods and services needed to ensure that they do not become subordinated to the arbitrary will of another. For instance, your ability to obtain food, shelter, clothing, and medical care cannot be dependent on the good will of a potential employer. Similarly, we can say that the economic liberty of working requires that 
people are not subject to forms of arbitrary power in the workplace and labour market which make them subordinate to others. For example, someone would lack this liberty if they are lumped with a tyrannical boss whose orders could never be contested by their employees.

Are contemporary workers genuinely unfree though? The champion of liberty of contract could first point to the right of exit which separates the modern waged or salaried employee from the chattel slave, feudal serf, or indentured servant. Since workers are not bound to their current employer, then they need not endure the arbitrary authority of their boss any longer than they choose to do so. Thus, it seems that workers are only ever bound by authority that they have themselves contractually authorised, such that claims of domination are overblown. However, this response overlooks the possibility of what the radical republican theorist Alex Gourevitch calls 'structural domination', whereby 'an unequal structure of control over productive assets" leads to workers being "dominated by a number of agents, but not any single, given agent in particular." ${ }^{30}$ In other words, the ability to exit any specific employment relationship does not entail the ability to exit all employment relationships. Thus, workers can be dependent on the will of the owners of productive assets as a whole, even if they are not necessarily dependent on the will of any one such owner. This structural domination can then force workers into particular relationships of domination when all their available options for economic survival require them to subordinate themselves to the arbitrary power of some employer. As Ivor Southwood puts it, the worker in this situation is often akin to "a prisoner whose jailer tosses him a bunch of keys to identical cells." 11

The second ground for pushing back against the idea that contemporary workers are dominated is to point to legal constraints external to the labour contract, which constrict the arbitrariness of employer authority. When the ideal of liberty of contract is advanced without the background protections of labour law, it may be plausible to say the freedom of the worker is not secured, but with some extra-contractual legal checks on employer power, then perhaps 
the situation is more benign. Consider legislation making racial, gender, and disability discrimination illegal in recruitment; mandating a minimum wage; limiting working time; requiring rest breaks; outlawing sexual harassment; restricting unfair dismissal; guaranteeing rights to join a trade union; establishing minimum safety standards; and so on. When present, each of these measures restricts the untrammelled authority of employers, and so lessens their arbitrary power over workers.

Yet, the power of employers need not be absolute in order to be substantively arbitrary. It is sufficient for economic domination that a person's access to some of the economic capabilities necessary to stand in relationships of civic equality - including not only capabilities to fulfil basic material needs but also to stand in economic relationships characterised by respect and opportunities for political agency - hinges on the uncontrolled decisions of others. For instance, even when some regulations are in place, the employer often has great latitude to determine work pace, alter job roles, assign and withdraw shifts, commence disciplinary proceedings, and shape the physical and social environment where work takes place. Even in those areas that are supposed to be tightly legally governed, such as wrongful dismissal and minimum wages, the effective ability to enforce the law is often lacking, especially where union representation is low and the threat of employer retaliation is hard to defend against. Furthermore, the social position occupied by managers often allows them to enjoy considerable informal authority, which can enable them to goad staff into working longer, harder, and in worse conditions than the law itself allows. Thus, while legal protections shape aspects of employment relationships, these are not always effective, and inevitably leave unregulated a significant subset of the powers of employers over their workers. When this unregulated power is extensive enough to threaten secure access to the economic capabilities necessary for civic equality, then we can identify economic domination. 
Neither exit rights nor existing regimes of legal regulation are sufficient to immunise most contemporary workers from dominating power in the workplace, so long as those workers are economically dependent on some employers. What institutional forms will secure republican economic liberty then? Cicero thought landed property worked by the unfree was necessary. Early modern republicans - from Harington and Sidney to Thomas Jefferson favoured the agrarian self-dependence of farmers. Neither of these are remotely promising routes today in egalitarian and post-agricultural societies. Several contemporary republicans instead support property-owning democracy. Of such a property-owning democracy, Rawls says its background conditions "work to disperse the ownership of wealth and capital, and thus to prevent a small part of society from controlling the economy, and indirectly, political life as well." 32 The liberal republican Alan Thomas endorses this - telling us that widespread capitalownership in particular, 'increases independence from 'undue influence' and domination by others". ${ }^{33}$ However, property-owning democracy does not itself establish workplace democracy. Workers can own a share of their workplace while its internal constitution remains undemocratic - earning them dividends as small stakeholders but little effective control over their working lives, and so continued vulnerability to the dominating authority of their employer. Furthermore, private ownership of productive property leaves property-owners exposed to significant economic risk due to the failure of firms - doubly so if workers are supposed to have a property stake in their own workplaces. Thus, property-owning democracy has significant limitations as a route to republican economic freedom.

We should instead look to socialist means to bring about republican ends. ${ }^{34}$ Such a socialist republicanism need not presuppose a command economy run by distant mandarins. Instead, it recommends a multiplicity of self-managing workplaces operating within mandates democratically determined by a citizenry who in turn benefit from a guaranteed provision of fundamental economic goods and services. The aim then is to secure economic freedom for 
workers and citizens as a whole in the form of undominated relational independence on the foundation of socialist institutions. Public ownership of productive property provides a basis for a combination of democratic control over firms and worker control within them. This would allow the arbitrary power currently held by managers, owners, and shareholders to be dissolved. Socialist welfare provisions would also bolster the relational economic independence of workers and non-workers alike by providing unconditional access to basic economic goods and services.

We may, however, be concerned that the theory of freedom at the heart of this project remains objectionably individualistic. We saw that Debsian socialist republicanism was focused on securing each individual's economic freedom - but shouldn't socialists strive for collective freedom rather than individual freedom? Furthermore, might aiming at economic independence be misguided, insofar as none of us can achieve complete independence from others in modern societies, even if that were remotely desirable?

Socialist republicans do seek economic independence for individuals but not without qualification: they do not pursue autarky and only eschew dependence on those social relationships that facilitate certain kinds of arbitrary power. This is compatible with roundly condemning what Hannah Arendt has called "the ideal of uncompromising self-sufficiency and mastership". ${ }^{35}$ Indeed, dependence upon others in some respects - including bonds of care, cooperation, and support - is the foundation of the independence from subjection to the arbitrary will of powerful economic actors which socialist republicans seek. A "relational structure of independence" of this kind has been emphasised by republican feminists such as Mary Wollstonecraft. ${ }^{36}$ Thinkers in the radical republican tradition are aiming for a relative rather than absolute independence, and do not offer us "a critique of our interdependence but of how that interdependence is organized". ${ }^{37}$ If republican freedom is always social freedom anchored in their social status within a community, then this is doubly so for socialist 
republicanism, which tells us that our freedom also presupposes solidaristic action, social control over property, and democratic control within the workplace. Freedom can legitimately be ascribed to the individual rather than a collective, even if the project of achieving it is ineliminably social in its methods and aims.

\section{Reproductive Work}

Our analysis so far has concentrated on paid work in the formal economy. But a huge share of work is not of this kind - in particular, much of the work that goes into social reproduction takes the form of unpaid housework, gestation, childrearing, and emotional labour necessary to reproduce the labour-power of workers, and which has predominantly fallen on the shoulders of women. Radical republican thought has concentrated on the relationship between the worker and their boss, as well as the wider socio-structural position of paid workers which leave them subordinated to the owners of land and productive opportunities. But can a radical republicanism also make sense of the situation of those doing unpaid reproductive work?

In principle, the absence of a formal boss or supervisor for unpaid reproductive work, and the fact that much of it is undertaken in the home among intimates rather than among colleagues with looser bonds of mutual affection, might suggest that domination is unlikely to be a significant problem. Of course, such a supposition dissolves on contact with reality. The reproductive worker can lack an official superior who superintends activities like cleaning, caring, copulating, and cooking, but overbearing partners and relatives are often able to take on this role, dictating what kinds of work must be done, for how long, and to what standard, while arbitrarily administering emotional or physical punishment for non-compliance, without the formal checks on disciplinary action present in many paid workplaces. Naturally, this power is no less arbitrary or effective for being legally unsanctioned. 
Republicans can also identify obstacles to the freedom of unpaid reproductive workers which are more diffuse than power held by identifiable individuals who invigilate them. When performance of this work is a condition of material support within households, then structural domination emerges. While there is no necessity to enter any particular relationship where reproductive work is demanded, there remains an imperative to enter some such relationship. Furthermore, even in the absence of individual dominators supervising the reproductive work process, there are concerns about the subordinating effects of social norms in the regulating the kinds and intensity of reproductive work that someone feels compelled to undertake. Consider rising standards of cleanliness, increasing expectations as to the healthiness of children's diets, or gendered norms of emotional availability and comforting - which are often socially determined rather than imposed and enforced by a specific partner or relative. The internalisation of such norms, or the fear of wider social opprobrium for breaking them, can leave someone effectively subject to alien power over which they have little control in their performance of reproductive work. Some republicans have urged that the "long history of women's marginalisation" should lead us to be sensitive to the "potential for prejudicial or exclusionary social norms to become entrenched and thus to prolong patterns of domination". ${ }^{38}$ Challenging and reshaping social norms that regulate the domain of unpaid reproductive work can be a particularly important focus of the "extremely slow, uncertain and open-ended project" of social and cultural transformation that these republicans advocate.

Threats to the republican economic liberty of working are joined by threats to the liberty of ownership for reproductive workers too. Nancy Fraser observes,

capitalist societies have separated the work of social reproduction from that of economic production. Associating the first with women and the second with men, they have remunerated 'reproductive' activities in the coin of 'love' and 'virtue', while compensating 'productive work' in that of money. ${ }^{39}$ 
This differential control over money which arises from a gendered division of labour and distinct treatment of reproductive work has important implications for the economic freedom of women reproductive workers. For example, if a husband can decide not to give his homemaker wife any housekeeping money this month because he would rather spend it on betting or drinking, and she has no independent means of supporting herself, then she will be personally dominated by him. Her access to civic capabilities - from food and clothes to protection from social shame - hinges on his arbitrary will. Domination obtains here even if the husband does decide to hand over the money, since his wife's fate is always dependent on his goodwill.

Some remedies to the problem of the domination of unpaid reproductive workers are familiar: the provision of domestic violence shelters and equitable divorce laws, for instance, which would go some way to increasing the possibility of exit from dominating domestic relationships. Other solutions rooted in a socialist republican approach are more economically radical. An unconditional basic income and services - including universal public housing would strengthen the economic basis for exiting relationships marked by dominating unpaid reproductive work and not simply dominating paid productive work. The credible threat of leaving, even if it is not carried out, can also have a disciplinary effect on dominators, moving the balance of power away from them. Furthermore, the move to socialise or communise reproductive activities, such as childcare, laundry, and cooking, would shift the locus of reproductive work away from the seclusion of the home, and therefore the stronghold of intrafamilial power.

\section{Platform Capitalism}


New forms of working might be thought to blunt the radical republican analysis of arbitrary power in the workplace. Consider the rise of what Nick Srnicek has called "platform capitalism", whereby companies use proprietary digital infrastructure to intermediate between users while collecting data on their interactions. ${ }^{40}$ The use of digital platforms in some sectors has led to certain management functions being offloaded onto the digital architecture of the platform rather than being directly controlled by a human supervisor. For instance, take taxi and food delivery companies such as Uber and Deliveroo, which connect drivers and customers via apps which operate on the basis of algorithmic decision-making. On some shifts for such workers, there may be no direct interaction with a human manager, with the app determining the parameters of the labour required. Thus, there seems to be an absence of the human will in the direction of such work. Whether we find this chilling or liberating, does it not make a republican focus on arbitrary power redundant? How can there be arbitrariness stricto sensu without the presence of an unconstrained will?

The disappearance of the will in such platform-mediated work is an illusion. While there may be little continual active supervision by a human manager, these managers can retroactively monitor the activity of workers based on data collected by the app itself and customer feedback. Likewise, managers will exert second-order control over the algorithm itself, with few checks on their authority to thereby radically alter the conditions of work. Thus, even if immediate managerial interventions are less frequent, there remains uncontestable power in the shaping of the digital platform itself. The boss is still present, then, even if they wear the mask of the machine. Furthermore, workers can still be subject to the direct arbitrary power of managers in other respects, such as being quietly sidelined by means of a reduction in shifts if suspected of engaging in union activities. This is not to say that platform-mediated power over workers is of no interest from the standpoint of republican economic liberty. Indeed, the relative depersonalisation of power over workers in their working life means that 
the incentive to indulge, flatter, or curry favour with a particular manager will often be lessened, even if surveillance and micromanagement of workers can be ramped up in other respects. This is an important shift in the microdynamics of power at work. Nevertheless, it does not make domination impossible in platform-mediated work.

\section{Digital Surveillance}

Other workplace technologies can also trigger republican concerns about the extent of the control employers can exercise overs workers. Consider further opportunities for surveillance afforded by new modes of work and new methods for observing workers - from the monitoring of online communications to the recording of performance metrics. ${ }^{41}$ For instance, the collection of these metrics can include the automated logging of the number of phone calls answered per hour, or the use of wearable tech able to detect the speed and efficiency of employee activity, such as the rate and type of warehouse tasks completed on a shift. There is more at stake here than the privacy of workers - the intensity of the oversight to which they are subjected also threatens their republican liberty. Orlando Lazar has rightly observed that increases in the scope of the surveillance of workers can leave them more vulnerable to employer invigilation, even in the absence of the actual exercise of arbitrary power. ${ }^{42}$ Invigilation occurs when another agent remains ready to intervene to override someone's choice should that person depart from the invigilating agent's will. In such cases, the invigilated agent acts only by the implicit permission of the invigilating agent, irrespective of whether any correction of behaviour happens. Of course, the knowledge that such a correction is always possible - that the boss can swoop in if the nature or pace of the worker's activity displeases them - is often sufficient to keep someone in line. 
The range of digital surveillance now faced by workers often extends beyond the workplace itself - whether as a result of the health monitoring mandated by some corporate wellness programmes, or more pedestrian snooping on workers' social media activities by their employers. ${ }^{43}$ Elizabeth Anderson has pointed out that the threat to republican liberty for the worker outside the workplace from such employer attention is particularly intense under legal regimes of at-will employment. Furthermore:

Because most employers exercise this off-hours authority irregularly, arbitrarily, and without warning, most workers are unaware of how sweeping it is. Most believe, for example, that their boss cannot fire them for their off-hours Facebook postings, or for supporting a political candidate their boss opposes. Yet only about half of U.S. workers enjoy even partial protection of their off-duty speech from employer meddling. ${ }^{44}$

The online trail left by everything from ordinary socialising to political organising often enables employers to exercise a greater degree of control over the lives of workers after they have officially clocked off than was once the case. Again, this can produce a chilling effect, with workers self-censoring their speech, or thinking twice about who they are seen associating with, even without the active intervention of the employer in forbidding or authorising their activities. It is this virtual control that republican conceptions of domination are particularly suited to capture.

\section{Post-Work}

Sceptics might wonder whether another development will soon render a radical republican approach to work redundant. Consider the now-familiar statistics about the potential for automation to destroy jobs: Frey and Osborne found that $47 \%$ of jobs in the U.S. can be computerised, and a 2017 McKinsey study concluded that even with currently existing 
technology, then at least $30 \%$ of the activities in $60 \%$ of occupations are amenable to automation. ${ }^{45}$ Furthermore, there are grounds to doubt that new jobs will arise to take the place of those which are destroyed in this way. So, is this not precisely the wrong time to be resurrecting a republican conception of freedom at work, when there will be fewer and fewer jobs to be free in? However, even on maximalist predictions about the effects of automation, then waged and salaried work will still be with us for decades to come. If that is the case, then we still need to confront the problems of power in the workplace and the labour market - which radical republican resources can help us do. Indeed, the restructuring of the workforce that automation is precipitating provides an occasion to challenge models of work which presuppose the subordination of workers. But this will only be successful if workers are powerful, savvy, and organised enough to push for changes in the governance structures in the workplace and not simply the size of their pay-packets.

A deeper challenge starts not from work's availability but its desirability, with postwork theorists pushing for the reduction or elimination of work. ${ }^{46}$ Does radical republicanism pull in the opposite direction by implicitly defending the value and dignity of work so long as it is undominated and therefore free? No: radical republicans do not glory in work - even free work. It is not only freedom in work that radical republicans want to secure but freedom from work. For instance, the labour republicans sought a "proportionate share of the leisure which the inventions of the age permit." ${ }^{\prime 4}$ In explaining why time outside of work is important, they appeal to the value of self-development. For instance, the labour republicans tell us their goal is to secure "to the workers sufficient leisure in which to develop their intellectual, moral and social faculties". ${ }^{48}$ We find labour republicans like George McNeill pushing for a reduction in working hours in order to create "more time for the development of the moral and mental qualities through opportunities of civilization, observation and association". ${ }^{49}$ As he puts it, "the busy man" is "but a narrow man", whereas "a reduction of the hours of labor" will "lift 
the laborer to a higher level of manhood", providing "more time for the employment of their faculties for the greater gain of their moral and mental growth". ${ }^{50}$ Furthermore, this appeal to self-development is not simply orthogonal to the republican liberty of workers. For instance, another Knight tells us,

man requires such surroundings as will enable him to develop and progress. These surroundings should be entirely independent of the good-will or caprice of his fellow men. If it be not so, man cannot be said to enjoy liberty. ${ }^{51}$

We might reformulate this claim as follows: undominated opportunities for self-development are a necessary condition of freedom.

Thus, radical republicanism offers us a rationale for a reduction in work: it leaves us with more time and energy for self-development. But it also thereby provides a reason for transforming work - eliminating or automating those tasks which are not conducive to selfdevelopment, such as repetitive low-skill drudge work. Conversely, it suggests that those work activities which do prompt self-development are less important to avoid, even if it is ultimately better that they are undertaken without the dull compulsion of economic relations. Radical republicanism is ultimately compatible with most kinds of anti-work politics and has an account of the importance of reducing the time spent at work in order to make room for both individual and collective self-development.

\section{Conclusion}

I have developed a socialist republican conception of economic liberty which is friendlier to the interests of workers than market conceptions of economic freedom which emphasise liberty of contract. This republican conceptual framework draws together concerns about worker power, civic equality, secure access to economic goods and services, and the importance of 
leisure - showing how deficits in the provision of each can result in economic domination. It also underpins a series of measures intended to reduce domination, including public ownership of productive property, workplace democracy, and robust unconditional basic income and services. I have argued that this approach can make sense of the liberties of working and ownership of not only paid workers in the 'productive' economy but also unpaid reproductive workers. Furthermore, it can accommodate changes in the nature of some work which has been driven by the emergence of platform-mediated management of labour. Finally, I have argued that trends in automation do not render a republican analysis of work irrelevant, and that a radical republican framework emphasis on self-development can help us determine which aspects of post-work politics to prioritise. Thus, I submit that we should bring radical republican ideas to bear on thinking about the future of work. ${ }^{52}$

\footnotetext{
${ }^{1}$ Isuelt Honohan, Civic Republicanism (London: Routledge, 2002).

${ }^{2}$ Clifford Ando, “'A Dwelling Beyond Violence': On the Uses and Disadvantages of History for Contemporary Republicans," History of Political Thought 31, no. 2 (2010), 185.

${ }^{3}$ Niclas Berggren, “The Benefits of Economic Freed om: A Survey”, The Independent Review 8, no. 2 (Fall 2003), 193.

${ }^{4}$ James Gwartney, Robert Lawson, Joshua Hall, and Ryan Murphy, Economic Freedom of the World: 2019 Annual Report (Vancouver: Fraser Institute, 2009), 1-2.

${ }^{5}$ See Amy Dru Stanley, From Bondage to Contract: Wage Labor, Marriage, and the Market in the Age of Slave Emancipation (Cambridge: Cambridge University Press, 1998).

${ }^{6}$ William Graham Sumner, What Social Classes Owe to Each Other (New York: Harper \& Brothers, 1883), 26.

${ }^{7}$ William Lloyd Garrison, “Is the Cause Onward," Independent, 14 $4^{\text {th }}$ January 1869.
} 
${ }^{8}$ William Lloyd Garrison, “Chattel Slavery and Wages Slavery,” Liberator, $1^{\text {st }}$ October 1847.

${ }^{9}$ E.L. Godkin, “The Labor Crisis,” North American Review 105 (July 1867), 183.

${ }^{10}$ E.L. Godkin, “The Future of Capital,” Nation, $22^{\text {nd }}$ June 1871, 429-30.

${ }^{11}$ See Eric Foner, The Story of American Freedom (New York: W.W. Norton, 1998), ch. 6.

${ }^{12}$ Lochner v. New York, 198 U.S. 45 (1905).

${ }^{13}$ Mercer Mining and Manufacturing Company of Ohio, "Article of Agreement," reprinted in National Labor Tribune, $8^{\text {th }}$ May 1875; Lochner, Story, 123.

14 John Mitchell, “The Workingman's Conception of Industrial Liberty", American Federationist 17 (May 1910), 407.

15 John Tomasi, "Democratic Legitimacy and Economic Liberty", Social Philosophy and Policy 29, no. 1 (2012), 54.

${ }^{16}$ Cicero, On Duties, M.T. Griffin and E.M. Atkins (eds.) (Cambridge: Cambridge University Press, 1991), II.78, 95.

${ }^{17}$ Algernon Sidney, Discourses Concerning Government (London: J. Darby, 1704), III.41, 397.

${ }^{18}$ Sidney, Discourses, III.41, 397.

${ }^{19}$ Robert Taylor, Exit Left: Markets and Mobility in Republican Thought (Oxford University Press, 2017), 52; Robert Taylor, "Republicanism and Markets", Republicanism and the Future of Democracy, Yiftah Elazar and Geneviève Rousselière (eds.) (Cambridge: Cambridge University Press, forthcoming), 202.

${ }^{20}$ Sidney, Discourses, III.21.

${ }^{21}$ Anon, “What Is It to Be a Slave?", Labor Leaf 1 , no. 47, 30 ${ }^{\text {th }}$ September 1885.

${ }^{22}$ George McNeill, The Labor Movement: The Problem of To-Day (New York: The M. W. Hazen Co, 1892), 456.

23 Anon, 'Chapters on Labor: Chapter VIII (Continued)', Journal of United Labor, 25 ${ }^{\text {th }}$ December 25 1885, 1153. 
${ }^{24}$ Aristotle, Rhetoric, in The Complete Works of Aristotle, ed. Jonathan Barnes (Princeton, 1984), I.9, 1367a32.

${ }^{25}$ Eugene Debs, “The Social Democratic Party,” The Independent [New York] 52, no. 2699, $23^{\text {rd }}$ August 1900.

${ }^{26}$ Eugene Debs, “The National Platform Explained”, Social Democratic Herald 5, no. 4, 26 ${ }^{\text {th }}$ July 1902.

${ }^{27}$ Eugene Debs, "'It is Something More Than a Strike": Speech in Chicago at Kuhn's Park (August 1, 1897)', Chicago Chronicle 3, no. 67, $2^{\text {nd }}$ Aug 1897.

${ }^{28}$ For further discussion of republican ideas in Debs' political writings, see Tom O'Shea, “What is Economic Liberty?", Philosophical Topics 49, no. 1 (in press).

${ }^{29}$ For a capabilities-based account of worker domination of this kind, see Tom O'Shea, “Are Workers Dominated?" Journal of Ethics and Social Philosophy 16, no. 1 (2019).

${ }^{30}$ Alex Gourevitch, "Labor Republicanism and the Transformation of Work," Political Theory 41, no. 4 (2013), 596, 602.

${ }^{31}$ Ivor Southwood, The Uncomplaining Body (London: Manual Labours, 2015), 9.

${ }^{32}$ John Rawls, Justice as Fairness: A Restatement (Cambridge, MA: Harvard University Press, 2001), 139.

33 Alan Thomas, Republic of Equals: Predistribution and Property-Owning Democracy (Oxford: Oxford University Press, 2017), 146.

${ }^{34}$ See Tom O’Shea, “Socialist Republicanism”, Political Theory 48, no. 5 (2020), 548-72.

${ }^{35}$ Hannah Arendt, The Human Condition (Chicago: University of Chicago Press, 1958), 234

${ }^{36}$ Alan Coffee, "Freedom as Independence: Mary Wollstonecraft and the Grand Blessing of Life”, Hypatia 29, no. 4 (2014), 908-24, 911.

${ }^{37}$ Gourevitch, "Labor Republicanism and the Transformation of Work," 605. 
38 Alan Coffee, "Two Spheres of Domination: Republican Theory, Social Norms and the Insufficiency of Negative Freedom", Contemporary Political Theory 14, no. 1 (2015), 48 and 57. See also, Alan Coffee, "Mary Wollstonecraft, Freedom and the Enduring Power of Social Domination", European Journal of Political Theory 12, no. 2 (2013).

${ }^{39}$ Nancy Fraser, “Contradictions of Capital and Care”, New Left Review 100 (July-Aug 2016), 102.

${ }^{40}$ Nick Srnicek, Platform Capitalism (Cambridge: Polity Press, 2017).

${ }^{41}$ See Kirstie Ball, "Workplace Surveillance: An Overview”, Labor History 51, no. 1 (2010);

Phoebe Moore and Lukasz Piwek, "Regulating Wellbeing in the Brave New Quantified Workplace", Employee Relations 39, no. 3 (2017); Ifeoma Ajunwa, Kate Crawford, and Jason Schultz, "Limitless Worker Surveillance”, California Law Review 105, no. 3 (2017).

42 Orlando Lazar, "Time For What We Will: The Anti-Domination Case for Less Work" (Challenging the Work Society Workshop, 2019). On invigilation in republican political philosophy, see Philip Pettit, On the People's Terms: A Republican Theory and Model of Democracy (Cambridge: Cambridge University Press, 2012), 60-4.

${ }^{43}$ On wellness programmes and surveillance, see Ajunwa, Crawford, and Schultz, "Limitless Worker Surveillance", $763 \mathrm{f}$.

${ }^{44}$ Elizabeth Anderson, Private Government: How Employers Rule Our Lives (and Why We Don't Talk About It) (Princeton: Princeton University Press, 2017), 39-40.

${ }^{45}$ Carl Benedikt Frey and Michael Osbourne, "The Future of Employment: How Susceptible Are Jobs to Computerisation?", Technological Forecasting and Social Change 114 (2017); James Manyika, Michael Chui, Miremadi, Mehdi et al., A Future That Works: Automation, Employment, and Productivity (San Francisco: McKinsey Global Institute, 2017).

${ }^{46}$ See Kathi Weeks, The Problem With Work: Feminism, Marxism, Antiwork Politics, and Postwork Imaginaries (Durham: Duke University Press, 2011); Nick Srnicek and Alex 
Williams, Inventing the Future: Postcapitalism and a World Without Work (London: Verso, 2015); David Frayne, The Refusal of Work: The Theory and Practice of Resistance to Work (London: Zed Books, 2015).

${ }^{47}$ The Master Workman of L A 1573, 'An Essay on the Evils Resulting from Long Hours and Exhaustive Toil', Journal of United Labor 2, no. 5-6, $15^{\text {th }}$ October 1881.

${ }^{48}$ McNeill, Labor Movement, 485.

${ }^{49}$ McNeill, Labor Movement, 477.

${ }^{50}$ McNeill, Labor Movement, 482, 463, 484.

${ }^{51}$ Anon, "Industrial Ideas Chapter I," Journal of United Labor 8, no. 3 (10 ${ }^{\text {th }}$ June, 1886), 2085. For further discussion, see Alex Gourevitch, From Slavery to the Cooperative Commonwealth: Labor and Republican Liberty in the Nineteenth Century (Cambridge: Cambridge University Press), ch. 4.

${ }^{52}$ I would like to thank Amelia Horgan and Ben Turner for their comments on an earlier draft, as well as the organisers and participants in the workshops on the Future of Work held at MANCEPT in September 2018. 